\title{
Primary Sarcomatoid Carcinoma of the Skin
}

\section{Anastasios D Papanastasiou, Martha Nifora, Zoi Stamou and Maria Repanti}

Department of Pathology, Patras General Hospital, Patras, Greece

Corresponding author: Anastasios D Papanastasiou, Department of Pathology, Patras General Hospital, Patras, Greece, Tel: +302610227902, Email: apapanasta@gmail.com

Received: 17 September 2016; Accepted: 20 September 2016; Published: 22 September 2016

Citation: Papanastasiou AD, Nifora M, Stamou Z, et al. Primary Sarcomatoid Carcinoma of the Skin. Arch Can Res. 2016, 4: 3.

\section{Case Blog}

Skin primary sarcomatoid carcinomas (SPSCs) are rare cutaneous neoplasms and their derivation is challenging [1,2].
SPSCs comprise a wide group of skin malignant neoplasms and differential diagnosis includes squamous cell carcinoma, melanoma, atypical fibroxanthoma, sarcoma as well as metastatic tumors [3,4] (Figure 1).

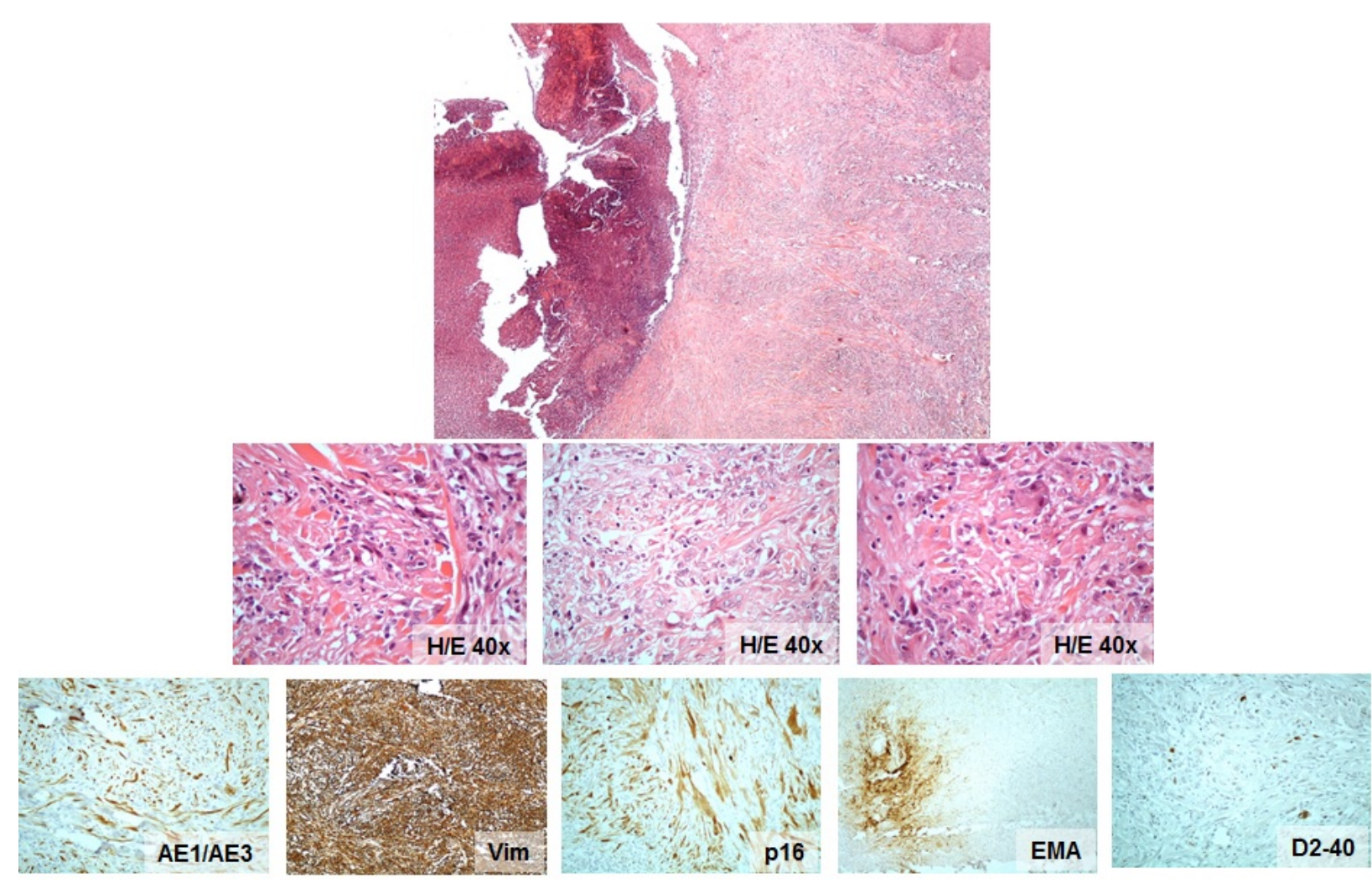

Figure 1 Histology and immunohistochemistry of a skin primary sarcomatoid carcinoma.

A 44-year-old woman presented with a crateriform ulcerated, rapidly growing tumor on her left thigh, $1.3 \mathrm{~cm}$ in its greatest dimension. The tumor was composed of spindle cells with marked nuclear atypia and pleomorphism. Multinucleated tumor giant cells were observed while necrosis was prominent and atypical mitotic figures numerous. No glandular formation or other conspicuous cell arrangement was observed. A benign adnexal tumor or foci of well differentiated carcinoma was not identified and this was attributed to the fact that the lesion was ulcerated and partially necrotic.
By immunohistochemistry, the malignant spindle cells in the specimen stained diffusely positive for cytokeratins (AE1/AE3, CAM5.2, CK7), vimentin and p16, while EMA, Smooth Muscle Actin (SMA), CD163, p53 and D2-40 were focally positive. CK20, p63, HMB45 and Desmin were negative in the malignant cell population.

The histological and immunohistochemical findings in conjunction with p16 and D2-40 immunoreactivity, points to a diagnosis of a primary sarcomatoid carcinoma of the skin, probably of eccrine derivation. 


\section{Acknowledgment}

Part of this work has been previously presented as a poster at the ESP Conference 2015 (PS-11-043).

\section{References}

1. Goh SG, Dayrit JF, Calonje E (2007) Sarcomatoid eccrine porocarcinoma: report of two cases and a review of the literature. J Cutan Pathol 34: 55-60.

2. Granter SR, Seeger K, Calonje E, Busam K, McKee PH (2000) Malignant eccrine spiradenoma (spiradenocarcinoma): a clinicopathologic study of 12 cases. Am J Dermatopathol 22: 97-103.

3. Roetman B, Vakilzadeh F, Krismann M (2002) Eccrine spiradenocarcinoma with unusual histiocytic giant cell components. Case report and review of the literature of a rare sweat gland tumor. Pathologe 23: 149-155.

4. McKee PH, Fletcher CD, Stavrinos P, Pambakian H (1990) Carcinosarcoma arising in eccrine spiradenoma. A clinicopathologic and immunohistochemical study of two cases. Am J Dermatopathol 12: 335-343. 